\title{
THE MARKETING OF THE LOCAL COMMUNITIES AS A TOOL FOR SUPPORTING THEIR SUSTAINABLE DEVELOPMENT
}

\author{
Calin Veghes ${ }^{1}$ \\ Diana Dugulan ${ }^{2}$ \\ Ioana Cecilia Popescu ${ }^{3}$
}

\begin{abstract}
The sustainable development of the local communities represents a rather sensitive topic, that incorporates and integrates elements related to the both concepts:"sustainable development”, respectively, ,local communities”. If an amount of marketing is added, things tend to become more complex, and, definitely, more complicated. The paper intends to answer, based on the information already available in the literature, to the following questions: what is a local community? What is the meaning of the sustainable development of a local community? Does marketing contribute to and support the sustainable development of the local communities? The answers to these questions are aimed to provide the appropriate background for defining the concept of marketing of the local communities and for the identification of the ways this concept may be employed in order to support the sustainable development of the local communities.
\end{abstract}

Keywords: Marketing, Local communities, Sustainable development

JEL classification: M31

\section{Introduction}

Local communities, as well as all the discussions about them, do not represent, from an economic and social perspective, a new topic in the academic landscape: they are mentioned in the scientific literature in the context of adapting the globalization to the local particularities, in relationship with the process of decentralization, perceived as a solution capable to generate and support the local and regional development, and, last but not least, connected to the increasing networking of the society, consequence of the existence and intensive employment of the socialization facilities provided by the modern means of communication.

Sustainable development also represents a concept widely circulated of whose history gains more and more consistence. The penetration of the concept has succeeded both horizontally and vertically: on a hand, there are few domains where sustainable development has not been incorporated or at least taken into consideration in the formulation and implementation of the specific strategies; on the other hand, following a rather top-down growth path, the sustainable development became a finality pursued not only by the governments, at a macroeconomic level, but also by the organizations, within their markets and fields of activity.

What about the presence of marketing in relationship with the local communities and their sustainable development? There references regarding the employment and contribution of marketing to the sustainable development of the local communities are rather rare, indirect and related to some specific areas of intervention, defined with a strong geographical significance, such as urban or local/regional marketing - where its specific concepts and tools are implemented aiming to support the development of a city, a local or a regional area.

\footnotetext{
${ }^{1}$ Academy of Economic Studies in Bucharest, Romania, email: c_veghes@yahoo.com

2 Academy of Economic Studies in Bucharest, Romania, email diana.dugulan@yahoo.com

${ }^{3}$ Academy of Economic Studies in Bucharest, Romania, email: ioanaceciliapopescu@yahoo.com
} 


\section{What is a local community?}

Definitions given to the communities by the different authors approaching the subject tend to insist rather on their sociological and anthropological characteristics having as result a combination of relative small scale, boundedness, and strong ties among their members without delineating with precision their boundaries as a local community (Marquis and Battilana, 2009). The origins of the term "community" are to be found in the old French word "communite", which derives from the Latin "communitas" ("cum" meaning "with/together" and "munus" meaning "gift"), a broad term used to describe fellowship or organized society (Beck, 1992).

Identifying the spatial limits or the geographical borders of the local communities - as the term "local" may quite impose - could bring a significant help in defining these communities: approaching the topic in the context of assessing the role of the heritage in the sustainable community tourism development, Joppe (1996) has observed that human settlements situated in the close proximity to a given heritage site could be considered as comprising a community, actually the local community around the site. Pacione (2001) has defined a local community as a group of people who share a geographic area and are bound together by common culture, values, race or social class.

Definitions of the local communities should consider the current administrative organization of the territory: they could represent an appropriate social construction unit in terms of listening to the community, empowering it, or even assessing the economic or other benefits to the local economy (Hampton, 2005). Linking the administrative structures with the decentralization process, Zhao (2009) has observed that local communities result after this process as it involves a shift of the power and responsibilities from central government to local governments, local communities, and the private sector. Political aspects must be regarded in the definition of these communities as many of the development initiatives need to take place at the local level and the local government is increasingly recognized as a new forum for bottom-up political decision-making prioritizing the needs of local communities (Evans, 2009).

The available resources a community may employ in order to support its development should also be considered in the definition of the local community. According to the Svendsen and Sørensen (2007), these resources may include seven forms of capital: physical (productive and tangible assets such as production sites, machines, infrastructure and buildings), natural (nature assets), economic (liquid assets, such as money, bonds and stocks), human (formal education and professional training), social (network cooperation based on regular face-to-face interaction and trust), organizational (organizational structures and everyday practices in a local community enabling things to be done), and cultural (shared local culture and identity, primarily transmitted from parents to children through history). A resource-based definition of the local communities will have to take into account the community control over the local resources, that sometimes can be more conducive to conservation than to an effective employment of them in order to support the community development (Thoms, 2008), as well as the assessment of the fiscal impact of conducting economic activities of these resources that will become increasingly important as local governments face tighter budget constraints (Lamie et al., 2012).

As a synthesis of the points of view presented above, a possible definition of the local communities could regard them as an assembly of individuals, organizations, and institutions located in a certain geographical, historical and/or administrative area, sharing resources (physical, natural, economic, human, social, organizational, and cultural), visions, and scopes, joining efforts, and aiming to obtain common performances.

\section{Local communities and the sustainable development}

The most authoritative and frequently quoted definition given to the sustainable development is that provided by the United Nation's World Commission on Environment and 
Develoment in the Brundtland Report (1987), stating that it refers to the development meeting the needs of the present without compromising the ability of future generations to meet their own needs, and contains within it two key concepts: „needs” - in particular the essential needs of the world's poor, to which overriding priority should be given, and the idea of ,limitations" imposed by the state of technology and social organization on the environment's ability to meet present and future needs.

According to the World Bank (2001), meeting the needs of the future requires a responsible balance of the social (issues that impact people directly and that either help or hinder the process of improving the quality of life, such as equity, participation, empowerment, social mobility, and cultural preservation), economic (the system that determines how the limited resources needed to improve peoples' lives are distributed, such as services, household needs, industrial growth, agricultural growth, and efficient use of labor), and environmental (the natural resources - both renewable and non-renewable - that make up surroundings and help to sustain and better peoples' lives, such as biodiversity, natural resources, carrying capacity, ecosystem integrity, and clean air and water) objectives.

The European Union (2010) views the sustainable development standing for meeting the needs of present generations without jeopardizing the ability of futures generations to meet their own needs, providing a better quality of life for everyone, now and for generations to come. Sustainable development integrates immediate and longer-term objectives, local and global action, and regards social, economic and environmental issues as inseparable and interdependent components of human progress. The European view stresses the necessity that the society as a whole, as well as at the individual level, will embrace it as a guiding principle in the decisionmaking process.

Established and supported by the World Bank, the community-driven development projects stay at the intersection of the local community interests and sustainable development goals and represent an approach that gives control over planning decisions and investment resources to community groups and local governments. Operating on the principles of local empowerment, participatory governance, demand-responsiveness, administrative autonomy, greater downward accountability, and enhanced local capacity, typical community-driven development projects ask communities to prepare subproject proposals with the support of facilitators, compete over block grants to finance investments for local public goods, and to be responsible for implementation and maintenance of those investments. This approach promotes stakeholder involvement in all stages of the process from subproject identification to subproject maintenance (Labonne and Chase, 2011).

Monitoring the sustainability of the fishery system, Charles (1994) has proposed a holistic vision based on four components - community, ecological, institutional and socio-economic explicitly recognizing the importance of communities and their institutions (Charles, 1994).

The growth and development of a community is the product of the interplay of four inextricably linked factors - population, environment, organization and technology (Jepson, 2007): according to the model under the Childe thesis of urban ecology, the ability of a community to sustain itself depends on its adaptability to the changing conditions (environment), as a result of the ability of the community members (population) to react through their institutions (organization), to develop appropriate artifacts, tools and techniques (technology).

Sustainable development is not just about the allocation and management of the resources, but also about deciding who holds power and the pursuit of fundamental social, economic and cultural objectives aiming to secure basic human needs, equity, social justice and cultural diversity (Barker, 2005). Achieving a sustainable community requires a long-term, integrated, and systems approach to addressing economic, environmental, and social issues, both on micro (focusing on the individual features of a community) and macro (regarding the community as a holistic system) perspective (Chan and Huang, 2004).

In their study over the impact of the foreign investments over the local communities, Figlio 
and Bloningen (2000) have shown that foreign investment has considerably different effects on local communities than does domestic investment: foreign plants tend to significantly increase wages paid to workers in an industry in a local community, and also lead to substantially lower per capita government budgets inducing changes in local government budget allocations. These results allow consideration of the foreign direct investments as an important resource for the sustainable development of the local communities and support the initiatives of the local communities to promote themselves in order to attract foreign investors and to penetrate international markets.

Community participation in the sustainable development is essential for the success of this process: the intended beneficiaries should be encouraged to take matters into their own hands, to participate in their own development through mobilizing their own resources, defining their own needs, and making their own decisions about how to meet those (Stone, 1989). Viewing the community as the main actor in the development process based on the common resources, needs and decisions, Tosun (2006) has identified and described three types of participation: coercive (topdown, passive, mostly indirect, formal, focusing more on implementation than in sharing resulting benefits), induced (top-down, passive, formal, mostly indirect, with an increased focus on sharing the benefits, and a higher choice between the available alternatives and feedback), and spontaneous (bottom-up, active, direct, focusing on participation in decision making and implementation).

Local initiatives, as well as intra- and inter-community relationships support a bottom-up participatory approach and play an important and encouraging role in creating sustainability in rural spaces (Marsden and Smith, 2005). These initiatives must be backed by a positive attitude of the local communities' members: an investigation of the local communities' attitudes is important for the community development (Jimura, 2011). Unfortunately, there are not rare the cases in which the local communities, especially in the Third World countries, even having a supportive attitude towards the sustainable development, get few benefits due to the little control they have over the project implementation, not matching the financial resources available to external investors, and having rarely heard their views (Mowforth and Munt, 2003).

Asking himself how a sustainable local community - seen as a sustainable local economy functions, Berry (2010) suggests a set of rules that might be followed by a community: wealth.

1.Always ask of any proposed change or innovation impact on the community and its

2.Always include local nature (land, water, air, native creatures) within the community.

3.Always ask how local needs might be supplied from local sources (including the mutual help of neighbors).

4.Always supply local needs first (and only then think of exporting products, first to nearby cities, then to others).

5.Understand the ultimate unsoundness of the industrial doctrine of "labor saving" if that implies poor work, unemployment, or any kind of pollution or contamination.

6.Develop properly scaled value-adding industries for local products to ensure that the community does not become merely a colony of national or global economy.

7.Develop small-scale industries and businesses to support the local farm and/or forest economy.

8.Strive to supply as much of the community's own energy as possible.

9.Strive to increase earnings (in whatever form) within the community for as long as possible before they are paid out.

10. Make sure that money paid into the local economy circulates within the community and decrease expenditures outside the community.

11. Make the community able to invest in itself by maintaining its properties, keeping itself clean (without dirtying some other place), caring for its old people, and teaching its children.

12. See that the old and young take care of one another: the young must learn from the old, not necessarily, and not always in school. There must be no institutionalized childcare and no 
homes for the aged. The community knows and remembers itself by the association of old and young.

13. Account for costs now conventionally hidden or externalized: whenever possible, these must be debited against monetary income.

14. Look into the possible uses of local currency, community-funded loan programs, systems of barter, and the like.

15. Always be aware of the economic value of neighborly acts: the nowadays costs of living are greatly increased by the loss of neighborhood, which leaves people to face their calamities alone.

16. A rural community should always be acquainted and interconnected with communityminded people in nearby towns and cities.

17. A sustainable rural economy will depend on urban consumers loyal to local products: therefore, this economy will always be more cooperative than competitive.

The assessment of the sustainable development of the local communities can be conducted using a set of indicators used to measure the characteristics of society that address social, economic and environmental quality. The employment of these indicators should go beyond the simple measurement toward enhancing the overall understanding of environmental, economic and social problems facilitate community capacity building, and providing appropriate inputs to the local sustainable development initiatives and projects (Reed et al., 2006).

\section{So, what can marketing do for the local communities?}

The intervention of marketing in the sustainable development of the local communities has been anticipated even from the last decades of the twentieth century: creation of the concept of social marketing and the societal orientation of the marketing represent the sound proofs in this respect. The recent development of the information and communication technologies provided the necessary support for the individuals and organizations to connect and interact and supported the increased communization of the society.

As Kotler et al. (2010) have shown, the new marketing, now in its 3.0 version, leaves behind the product-centric and the customer-centric eras to rise to the human-centric era where consumers will be treated as active, anxious, and creative human beings: consumers will request for more participation in value creation, demand to have identified and fulfilled their deepest anxieties and desires, and ask for the appreciation of their creativity. The new marketing will encourage and support their active participation in networks and communities and will contribute to their transformation into a group of people with a common ideology who try together to achieve certain general goals. As long as this is nothing but the definition of the sustainable development viewed as a social movement (WordNet 2.0, Princeton University, 2003, quoted in Kates et al., 2005), the marketing may be seen as a catalyst of the sustainable development of the local communities providing these with the concepts and tools for the planning, implementation and monitoring of the specific projects.

Seen from this perspective, the marketing of the local communities can be defined as an assembly of marketing concepts and tools employed by the local communities in the projects, activities, and campaigns aiming to satisfy the needs and expectations of their members and to support the sustainable development of the community.

The major areas of the marketing intervention for supporting the sustainable development projects of a local community could be:

- the analysis of the marketing environment of the local community: its major goals are related to the identification and assessment of the opportunities and threats associated with the potential sustainable development projects, respectively of the strengths and weaknesses of the local community in terms of the available resources for supporting these projects. The framework provided by the SWOT analysis could serve for a proper positioning of the local communities in the 
overall context of the marketing environment, and provide the insight for their future development;

- the design of a marketing strategy for the sustainable development of the local community including distinctive components regarding the market of the community, the products and services provided, the prices of the specific offers, the channels used to make products and services available, and the communication with the consumers, public, and the members of the community. A set of criteria, more or less similar to those already certified by the marketing theory and practice, will be employed allowing the local communities to develop and adapt their versions of the marketing mix;

- the implementation of the marketing strategy through the plans and programs put in practice using the specific instruments and methods within an own effort of the local community or based on the cooperation with specialized providers of marketing services. The local communities should take into consideration the writing and implementation of an annual marketing plan as well as programming all the specific activities to be conducted;

- the control of the entire range of activities and campaigns using the appropriate management and marketing tools in order to assess their effectiveness and to recalibrate the design and implementation of the sustainable development projects.

Going further until to the level of the sustainable development projects, marketing may provide a valuable contribution in at least the following areas:

- research of the community needs in order to identify and assess them in a broader sense, to provide information about the members' related problems, visions, and expectations, and to delimitate the specific field of the future project and its overall scope;

- communication with the community members in order to inform about and to promote the project, get the appropriate support for it, and obtain the involvement from the members, respectively their active participation during the project implementation;

- communication with the stakeholders in order to inform them about the project, create a favorable attitude towards the project, and, generally, the local community, and to obtain the appropriate support in terms of the resources - financial, technical, human and information demanded during the project implementation;

- assessment of the project's impact and contribution to the sustainable development of the local community in terms of the members' attitude, opinions and satisfaction regarding the project's implementation.

\section{Conclusions and future research directions}

The sustainable development of the local communities cannot be imagined without a significant marketing component. Each local community, defined not necessarily in geographical or administrative terms, should assess its resources, join efforts, and aim to obtain the performances capable to provide a sound development of the community. With a list areas of intervention at the level of the whole process of sustainable development, and, also, at the level of the related projects, marketing provide the local communities with a consistent assembly of concepts and tools that can be used in planning, implementation, and monitoring of the projects.

The investigation of the scientific literature approaching the topics of "local communities", "sustainable development", and marketing (in connection with the "sustainable development of the local communities") reveals that sustainable development and local communities, in this specific order, are well-debated subjects both in an independent manner - with an important and relevant amount of related information - or in a common context - the term "sustainable community" being, probably, the most illustrative and meaningful in this respect.

Definitely, the marketing of the local communities is a less approached subject and there are not too many attempts to explain its content, usefulness, and contribution to the sustainable development of the local communities. Although the specific literature includes studies and articles approaching the economic dimension of the local communities development, some of these even 
particularized for certain industries, the lack of scientific information regarding the marketing of these communities is somehow surprising, but, in the same time, is creating an important research opportunity. The authors aimed to seize this opportunity by advancing a definition of the marketing conducted by and in the favor of the local communities, that has been presented as an assembly of marketing concepts and tools the local communities may integrate and employ within their projects, activities or campaigns having as major goal to satisfy the needs and expectations of their members, and, thus, to support the sustainable development of these communities.

The authors have identified four areas of the marketing intervention for supporting the sustainable development projects of a local community: the analysis of the marketing environment of the local community, the design of a marketing strategy for the sustainable development of the local community, the implementation of the marketing strategy, and the control of all the marketing related activities. Going further, to the level of a sustainable development project, the authors have proposed four directions of the marketing intervention: the research of the community needs, communication with the community members, communication with the stakeholders, and assessment of the project's impact and contribution to the sustainable development.

As the current approach is one of a conceptual nature, the authors aim to direct their future studies focusing on: (1) providing a better definition, from a marketing perspective, of the local communities, (2) structuring a set of indicators to be used in the assessment of the sustainable development of the local communities, (3) making more clear, both conceptually and operationally, the content of the marketing of the local communities, and (4) measuring the marketing contribution to the sustainable development of these communities.

\section{References}

1. Barker A., 2005. Capacity building for sustainability: towards community development in coastal Scotland, Journal of Environmental Management, 75, 11-19

2. Beck, U., 1992. Risk Society: Towards a New Modernity. London, Sage

3. Berry W., 2010. 17 rules for a sustainable local community, February 10, 2010, http://sustainabletraditions.com/2010/10/wendell-berry-17-rules-for-a-sustainable-localcommunity/, retrieved September 27th, 2011

4. Chan S.-L., Huang S.-L., 2004. A systems approach for the development of a sustainable community - the application of the sensitivity model (SM), Journal of Environmental Management, 72, pp. 133-147

5. Charles A.T., 1994. Towards sustainability: the fishery experience, Ecological Economics, 11, pp. 201-211

6. European $\quad 2010 . \quad$ Sustainable development, http://ec.europa.eu/environment/eussd/, retrieved at September 26th, 2011

7. Evans E., 2009. A framework for development? The growing role of UK local government in international development, Habitat International, 33, pp. 141-148.

8. Figlio D.N., Blonigen B.A., 2000. The Effects of Foreign Direct Investment on Local Communities, Journal of Urban Economics, 48, pp. 338-363.

9. Hampton M.P., 2005. Heritage, local communities and economic development, Annals of Tourism Research, Vol. 32, No. 3, pp. 735-759.

10. Jepson E.J., 2007. Characteristics and conditions on sustainable development policy?, Cities, 26 (6), pp. 434-447.

11. Jimura T., 2011. The impact of world heritage site designation on local communities - a case study of Ogimachi, Shirakawa-mura, Japan, Tourism Management, Vol. 32, pp. 288296.

12. Joppe M., 1996. Sustainable community tourism development revisited, Tourism 
Management, 17, pp. 475-479.

13. Kartajaya H., Setiawan I., Kotler Ph., 2010. Marketing 3.0: de la produs la consumator şi la spiritul uman, Bucureşti, Publica

14. Kates R.W., Parris T.M., Leiserowitz A.A., 2005. What is sustainable development? Goals, indicators, values, and practices, Environment: Science and Policy for Sustainable Development, 47 (3), pp. 8-21.

15. Labonne J., Chase R.S., 2011. Do community-driven development projects enhance social capital? Evidence from the Philippines, Journal of Development Economics, 96, pp. 348358.

16. Lamie R.D., Campbell W., Molnar W., 2012. The fiscal-geographic nexus: An overview of fiscal impact assessment in local policy development, Applied Geography, 32, pp. 54-60.

17. Marquis C., Battilana J., 2009. Acting globally but thinking locally? The enduring influence of local communities on organizations, Research in Organizational Behavior, 29, pp. 283302.

18. Marsden T., Smith E., 2005. Ecological entrepreneurship: sustainable development in local communities through quality food production and local branding, Geoforum 36, pp. 440451.

19. Mowforth M., Munt I., 2003. Tourism and sustainability: Development and new tourism in the Third World (Second edition). London, Routledge

20. Pacione M., 2001. Urban geography: A global perspective. London, Routledge.

21. Reed M.S., Evan F.D.G., Dougill A.J., 2006. An adaptive learning process for developing and applying sustainability indicators with local communities, Ecological Economics, 59, pp. 406-418.

22. Stone L., 1989. Cultural cross-roads of community participation in development: A case from Nepal, Human Organisation, 48 (3), pp. 206-213.

23. Svendsen G.L.H., Sørensen J.F.L., 2007. There's more to the picture than meets the eye: Measuring tangible and intangible capital in two marginal communities in rural Denmark, Journal of Rural Studies, 23, pp. 453-471.

24. Thoms C.A., 2008. Community control of resources and the challenge of improving local livelihoods: A critical examination of community forestry in Nepal, Geoforum, 39, pp. 1452-1465.

25. Tosun C., 2006. Expected nature of community participation in tourism development, Tourism Management, 27, pp. 493-504.

26. The World Bank, 2991. What is sustainable development, http://www.worldbank.org/depweb/english/sd.html, retrieved September 26th, 2011.

27. World Commission on Environment and Development, 1987. Our Common Future, Chapter 2: Towards Sustainable Development, http://www.un-documents.net/ocf-02.htm, retrieved September 25th, 2011.

28. Zhao L., 2009. Between local community and central state: Financing basic education in China, International Journal of Educational Development, 29, pp. 366-373. 